\title{
Nutritional content, nutraceutical properties, cultivation methods and economical importance of Lentinula: a review
}

\author{
Raghoonundon $\mathbf{B}^{1,2}$, Gonkhom $\mathbf{D}^{1,2}$, Phonemany $\mathbf{M}^{1,2}$, Luangharn $\mathbf{T}^{1}$, \\ Thongklang $\mathbf{N}^{1,2^{*}}$
}

${ }^{1}$ Center of Excellence in Fungal Research, Mae Fah Luang University, Chiang Rai 57100, Thailand

${ }^{2}$ School of Science, Mae Fah Luang University, Chiang Rai 57100, Thailand

Raghoonundon B, Gonkhom D, Phonemany M, Luangharn T, Thongklang N. 2021 - Nutritional content, nutraceutical properties, cultivation methods and economical importance of Lentinula: a review. Fungal Biotec 1(2), 88-100, Doi 10.5943/FunBiotec/1/2/6

\begin{abstract}
Lentinula is a wood-inhabiting agaric mushroom genus in Omphalotaceae. The genus comprises eight species, several of which are edible and highly prized. Lentinula edodes, commonly known as Shiitake, is one of the most cultivated species worldwide and considered as a traditional delicacy in Southeast Asia. With proven medicinal properties, the market value of $L$. edodes is expected to reach $\$ 447.7$ million in 5 years' time. In this paper, we review the nutritional content, nutraceutical properties, cultivation methods, and economic importance of Lentinula.
\end{abstract}

Keywords - edible mushrooms - Lentinula - market value- medicinal mushrooms.

\section{Introduction}

Consumption chains and food production are being affected by globalization (Kennedy et al. 2004). Food products are now available in a wide variety, higher quality, and lower prices. Many products are competing to appeal to consumers. Mushrooms have been consumed for centuries for their sensory characteristics and culinary attributes (Chang 2008, Roncero-Ramos \& DelgadoAndrade 2017). Mushrooms can be categorized as edible and medicinal according to their primary applications (Wang et al. 2014). Recently, many edible mushrooms have been highly regarded as functional foods for possessing enormous nutritive and medicinal values (Kalač 2013, Haro et al. 2020, Marçal et al. 2021). Growing demand for foods that are low in cholesterol and fat content and packed with nutrients is expected to escalate the growth of the global mushroom market (Mattila et al. 2001, Rathore et al. 2017). Edible mushrooms usually provide protein with higher biological efficiency than animal protein, leading to increased use of mushrooms as a substitute for meat (Bach et al. 2017, Kumar et al. 2017). With the increasing number of vegan populations, the global mushroom market is expected to further grow. Mushrooms contain several important compounds such as polysaccharides, phenolics, polyphenolics, ergosterols, and volatile organic compounds, which are responsible for numerous beneficial health properties including, anti-tumor, anti-oxidant, anti-hypercholesterolemia, anti-viral, anti-bacterial, and anti-diabetic effects (Barros et al. 2007, Guillamón et al. 2010, Thatoi \& Singdevsachan 2014, Hyde et al. 2019). Several studies have proved that mushrooms such as Agaricus basiliensis and Hericium erinaceus, contain beneficial compounds against chronic diseases, such as neurodegenerative diseases, cardiovascular diseases, and cancer (De Silva et al. 2012, Öztürk et al. 2015, Hyde et al. 2019).

Lentinula is a wood-inhabiting agaric genus in the family Omphalotaceae (Earl 1909). Several taxonomic studies have been done on this genus in several countries (Guzmán et al. 1997, 
Hibbett 2001, Moon et al. 2017, He et al. 2019) and to date, eight species (Table 1) are known (http://www.indexfungorum.org/). Wild populations of Lentinula occur in America, Asia, and Australia (Hibbett et al. 1998). Lentinula is best known as the genus of extensively cultivable shiitake mushrooms. Lentinula species are saprobic, usually causing wood decomposition especially in Fagaceae trees (Chang \& Miles 1987). Lentinula edodes also commonly known as shiitake is the second most cultivated mushroom species globally owing to its unique palatability (Chung et al. 2020). It approximately represents $25 \%$ of the worldwide mushroom productions (Zhao et al. 2019). In the light of emerging literature, this paper reviews the cultivation, nutritional value, medicinal properties, and economic importance of Lentinula.

Table 1 List of Lentinula species reported worldwide.

\begin{tabular}{ll}
\hline Species & References \\
\hline Lentinula aciculospora J.L. Mata \& R.H. Petersen & Mata \& Petersen (2000) \\
L. boryana (Berk. \& Mont.) Pegler & Pegler (1976) \\
L. edodes (Berk.) Pegler & Pegler (1976) \\
L. guarapiensis (Speg.) Pegler & Pegler (1983) \\
L. lateritia (Berk.) Pegler & Pegler (1983) \\
L. madagasikarensis Buyck, Randrianjohany \& Looney & Looney et al. (2021) \\
L. novae-zelandiae (G. Stev.) Pegler & Pegler (1983) \\
L. raphanica (Murrill) Mata \& R.H. Petersen & Mata \& Petersen (2001) \\
L. reticeps (Mont.) Murrill & Murrill (1915) \\
\hline
\end{tabular}

\section{Nutritional values}

Mushrooms have been a part of the human diet since antiquity. Fresh and preserved mushrooms have been consumed in many countries as a delicacy due to their nutritional, medicinal, and organoleptic values. Amongst all mushroom species in nature, more than 2000 species are edible (Kalač 2016, Li et al. 2021) but only 25 species are widely accepted as daily food worldwide (Valverde et al. 2015). At the moment 10-20 species are commercially cultivated worldwide (Kalač 2016). As an ingredient of gourmet cuisine, the demand for edible mushroom species is constantly increasing. Numerous findings on the health benefits of mushrooms and the introduction of processed food products incorporated with mushrooms further increase its popularity amongst consumers. Based on the Food and Agriculture Organization report, the global mushroom production grew to 11.89 million metric tons in 2019 (FAOSTAT, 2021) and approximately $5 \mathrm{~kg}$ of mushroom is consumed per person per year (Royse et al. 2017). Edible mushrooms are rich in protein and fiber content, with low fat and cholesterol content, making them ideal as biomedical ingredients of functional foods (Wang et al. 2021). As an essential nutrient in maintaining health, proteins have a large number of functions in the human body range from enzymes to being part of the body tissues (Bhutta et al. 2013). The protein value of dry mushrooms varies between $18.8 \%$ to $36.9 \%$, hence attracting attention as a viable alternative for high quality protein.

Table 2 Main nutritional compounds found in Lentinula.

\begin{tabular}{lll}
\hline Main compounds & Compositions & References \\
\hline Organic acids & Acetic, Ascorbic, Citric, Fumaric, Linoleic, & Finimundy et al. (2014), Kalač (2016), Li \\
& Malic, Myristic, Oleic, Palmitic, Stearic, et al. (2018), Zhao et al. (2019), Marçal \\
& Succinic, Tartaric, Tetradecenoic & et al. (2021) \\
Free sugars & Arabinose, Arabinol, Fucose, Galactose, & Finimundy et al. (2014), Kalač (2016), \\
& Glucose, Mannitol, Mannose, Ribose, Zhao et al. (2019), Marçal et al. (2021) \\
& Trehalose, Xylose & \\
Minerals & Ca, Cd, Fe, K, Mn, P, Rb, Zn & Finimundy et al. (2014), Kalač (2016), \\
& & Marçal et al. (2021) \\
Vitamins & B-complex, C, D & Finimundy et al. (2014), Kalač (2016) \\
\hline
\end{tabular}


Lentinula edodes is widely cultivated around the world and considered a traditional delicacy in Southeast Asia for their desirable tasty flavor. Unfortunately, due to the high moisture content and soft texture of the flesh, L. edodes is highly perishable when kept at room temperature (Marçal et al. 2021). Thus, L. edodes is mostly consumed in dried forms. Various studies have been done to investigate the nutritional values, with the results being varied concentrations of macronutrients when compared. Reis et al. (2012) reported an average of $79.78 \mathrm{~g} / 100 \mathrm{~g}$ for moisture content of $L$. edodes. Li et al. (2018) found that the protein content $(284.35 \mathrm{~g} / \mathrm{kg})$ of L. edodes was close to milk $(25.20 \%)$ and higher than rice and wheat, indicating it could be a good source of protein. Some other studies reported lesser amounts of protein content (Spim et al. 2021), but these differences could be attributed to the difference in substrates used, environmental conditions, phase of growing, and harvest (Siwulski et al. 2019). With low amounts of fats and higher fiber content, L. edodes could be an important component of a healthy diet from the view of modern nutrition (Vetter 2007, Günç Ergönül et al. 2013, Li et al. 2018, Spim et al. 2021). Besides providing key nutrients like proteins and carbohydrates, Lentinula has also been found to be a good source of functional compounds, minerals, and vitamins (Table 2). The addition of Lentinula species in the daily diet could increase the intake of micronutrients, without increasing calories or fat intake (Fulgoni \& Agarwal 2021).

\section{Nutraceutical properties}

The extraction of bioactive compounds from mushrooms has attracted a lot of interest during the last decades. Lentinula edodes has a very good history of producing polysaccharides macromolecules with proven therapeutic effects. Numerous studies have demonstrated anti-viral, anti-fungal and anti-microbial activities, anti-oxidant, anti-tumor and immunomodulatory effects from mycelial extracts and bioactive compounds of L. edodes (Table 3) (Kaneko \& Chihara 1992, Jong \& Birmingham 1993, Suzuki et al. 1994, Ishikawa et al. 2001, Maruyama et al. 2006, Wang et al. 2009, Lee et al. 2020, Wang et al. 2020). It is medicinally used for cancer, frequent flu and colds, bronchial inflammation, heart disease, hyperlipidemia, treatments of immune function (including AIDS), hypertension, infectious disease and fungal infections, diabetes, hepatitis, and regulating urinary inconsistencies (Hobbs 2000, Wasser 2005, Bisen et al. 2010, Wang et al. 2017, Cao et al. 2020). Intervention trials involving direct consumption of mushrooms are relatively few, nevertheless, those completed are usually well tolerated with few or no side effects (Shah et al. 2011, Yamaguchi et al. 2011, Suzuki et al. 2013).

Table 3 Biological activities of Lentinula edodes.

\begin{tabular}{|c|c|c|}
\hline Biological activities & $\begin{array}{l}\text { Polysaccharides/ } \\
\text { Bioactive compounds }\end{array}$ & References \\
\hline $\begin{array}{l}\text { Anti-microbial } \\
\text { activity }\end{array}$ & $\begin{array}{l}\text { Lentinula mycelial extracts, } \\
\text { 1,2,4,6-Tetrathiepane }\end{array}$ & $\begin{array}{l}\text { Kitzberger et al. (2007), Hearst et al. (2009), Rao et } \\
\text { al. (2009), Ciric et al. (2011), Tonucci-Zanardo et al. } \\
\text { (2015), Muszyńska et al. (2017), Garcia et al. (2021) }\end{array}$ \\
\hline Anti-cancer activity & $\begin{array}{l}\text { Lentinula mycelial extracts, } \\
\text { Ergosterol, Trilinolein }\end{array}$ & $\begin{array}{l}\text { Gu \& Belury (2005), Din et al. (2020), Joseph } \\
\text { et al. (2021) }\end{array}$ \\
\hline $\begin{array}{l}\text { Anti-bacterial } \\
\text { activity }\end{array}$ & $\begin{array}{l}\text { Cortinellin )nemotinic acid(, } \\
\text { Demethylincisterol A3, } \\
\text { Lentinamycin } \\
\text { )octa-2,3-diene-5,7-diyne-1-ol(, } \\
\text { Lentionine )1,2,3,5,6- } \\
\text { pentathiepane( }\end{array}$ & $\begin{array}{l}\text { Ishikawa et al. (2001), Hiroko et al. (2005), } \\
\text { Muszyńska et al. (2017), Fukushima-Sakuno (2020) }\end{array}$ \\
\hline Anti-fungal activity & $\begin{array}{l}\text { Cortinellin )nemotinic acid(, } \\
\text { Lentinamycin )octa-2,3-diene- } \\
\text { 5,7-diyne-1-ol(, Lentionine } \\
\text { 1,2,3,5,6-pentathiepane(, } \\
\text { Nona-3,5,7-triyne-1-ol, } \\
\text { Nona-7-ene-3,5-diyne-1-ol, } \\
\text { Octa-3,5,7-triyne-1-ol }\end{array}$ & Fukushima-Sakuno (2020) \\
\hline
\end{tabular}


Table 3 Continued.

\begin{tabular}{|c|c|c|}
\hline Biological activities & $\begin{array}{l}\text { Polysaccharides/ } \\
\text { Bioactive compounds }\end{array}$ & References \\
\hline Anti-viral activity & $\begin{array}{l}\text { Lentinan, } \\
\text { Lentinula mycelial extracts }\end{array}$ & $\begin{array}{l}\text { Rincão et al. (2012), Jang et al. (2017), Garcia et al. } \\
\text { (2021) }\end{array}$ \\
\hline Anti-tumour activity & $\begin{array}{l}\text { Lentinan, } \\
\text { Lentinula mycelial extracts }\end{array}$ & $\begin{array}{l}\text { Bisen et al. (2010), Tanaka et al. (2012), Zhong et al. } \\
\text { (2012), Luan et al. (2017) }\end{array}$ \\
\hline $\begin{array}{l}\text { Anti-inflammatory } \\
\text { activity }\end{array}$ & Lentinula mycelial extracts & $\begin{array}{l}\text { Crespo et al. (2017), Muszyńska et al. (2017), Ren et } \\
\text { al. (2018), Song et al. 2020) }\end{array}$ \\
\hline Anti-oxidant activity & Lentinula mycelial extracts & $\begin{array}{l}\text { Sasidharan et al. (2010), Finimundy et al. (2013), } \\
\text { Chowdhury et al. (2015), Jang et al. (2017), Seo et al. } \\
\text { (2017), Garcia et al. (2021) }\end{array}$ \\
\hline $\begin{array}{l}\text { Hypocholesterolemic } \\
\text { activities }\end{array}$ & $\begin{array}{l}\text { Eritadenine, } \\
\text { Lentinula mycelial extracts }\end{array}$ & $\begin{array}{l}\text { Enman et al. (2007), Nisar et al. (2017), Morales et } \\
\text { al. (2019) }\end{array}$ \\
\hline $\begin{array}{l}\text { Immunoregulatory } \\
\text { activities }\end{array}$ & Lentinula mycelial extracts & $\begin{array}{l}\text { Israilides et al. (2008), Muszyńska et al. (2017), Chen } \\
\text { et al. (2020), Murphy et al. (2020) }\end{array}$ \\
\hline
\end{tabular}

Amongst the produced polysaccharides, L. edodes mycelia extract (LEM), Lentinan and KS-2 are the ones with proven nutraceutical effects (Dennert \& Tucker 1973, Sasaki \& Takasuka 1976, Bisen et al. 2010). LEM is usually harvested before the growth of the stipe and cap. It is a heteroglycan- protein comprising $44 \%$ of sugars and $24.6 \%$ of protein (Israilides et al. 2008). The sugars consist mostly of pentose, glucose, and smaller amounts of fructose, galactose, and mannose (Sugano et al. 1985). Lentinan is a homo-polysaccharide with about one million molecular weights, in a triple helix structure (Aoki 1984, Israilides et al. 2008). The primary structure of the $\beta$-glucan consists of a $\beta$-(1-3)-glucose backbone with two (1-6)- $\beta$-glucose branches of each five-glucose unit (Saito et al. 1977, Lu et al. 2009). KS-2 is a complex $\alpha$-mannan peptide comprising mainly of amino acids serine, threonine, alanine, and proline, obtained from the extraction of L. edodes mycelia, followed by precipitation with ethanol (Fuji et al. 1978, Bisen et al. 2010). Eritadenine, formerly described as lentinacin (Chibata et al. 1969) and lentysine (Kamiya et al. 1969), is one of the secondary metabolites also extracted from L. edodes. Eritadenine, also known as 2(R), 3(R)dihydroxy-4-(9-adenyl) - butyric acid has been reported as an active component in lowering the blood cholesterol level (Chibata et al. 1969, Enman et al. 2007, Bisen et al. 2010).

Anti-bacterial, anti-fungal, and anti-viral properties of $L$. edodes have been reported in numerous studies (Hearst et al. 2009, Bisen et al. 2010, Rincão et al. 2012, Muszyńska et al. 2017, Fukushima-Sakuno 2020). Lenthionine, a peptide derived from L. edodes and bi [(methylsulfonyl) methyl] disulphide, derived from lenthionine, have been found to have strong anti-bacterial and anti-fungal activities (Yasumoto et al. 1971, Hirasawa et al. 1999, Kitzberger et al. 2007, Kupcova et al. 2018). Lentinan, another compound extracted from L. edodes, was reported to have strong inhibitory action against Mycosphaerella arachidicola (Lam \& $\mathrm{Ng} 2001$ ) and Staphylococcus aureus (Hatvani 2001). Lentinan has been proved to enhance the host resistance against viruses, bacteria, parasites and fungi (Chihara 1992). Lentinan was found to inhibit tumor growth by regulating the immune system through activating immune cells, promoting the $\mathrm{T}$ - and $\mathrm{B}$ lymphocyte proliferation and enhancing the activities of NK cells and stimulating the productions of different cytokines (Hou et al. 2008, Guo et al. 2009). It has also been used to treat patients with gastric cancers and malignant effusions and HIV-positive patients (Taguchi 1987, Gordon et al. 1995, Nakano et al. 1999, Ina et al. 2013, Zhang et al. 2018). LEM, lentinan, and KS- 2 act by activating the host's immune system. They are useful in the treatments of Hepatitis B as they inhibit the growth of cancer cells and boost immunity (Mizuno 1995, Chang 1996, Ahmed et al. 2011). Nucleic acid compounds in L. edodes extract have shown strong platelet agglutination inhibitive effect (Wasser \& Weis 1999, Morales et al. 2020). Extracts from L. edodes have also been found to have power-packed antioxidant properties (Sasidharan et al. 2010, Finimundy et al. 2013). 


\section{Cultivation methods}

Mushroom cultivation represented a market of USD 16.7 billion in 2021 and is estimated to reach a value of USD 20.4 billion by 2026 (Market Data Forecast 2021). Various sources suggest that humans have used wild mushrooms as food since the earliest time. The first cultivation of mushroom species took place almost 1600 years ago in China (Chang \& Miles 1987). In the 20 $0^{\text {th }}$ century, the extensive use of mechanized technology in mushroom cultivation revolutionized the cultivation techniques and production of mushrooms as food. The interest of consumers in wild as well as new species of edible mushrooms have led to trials of domestication by mushroom scientists to satisfy their demand.

Lentinula edodes is one of the ten most popular mushroom species brought into cultivation, which led to the drastic increase in the world's most cultivated mushrooms (Miles \& Chang 2004). For a long time, this mushroom has been valued for its taste, flavor, and medicinal properties. Lentinula was first cultivated in China between 1000 - 1100 A.D and later introduced to other parts of Asia. In the $20^{\text {th }}$ century, Japan and China competed as the leading producer of this mushroom (Chen 2001). After the Chinese new technologies involved in Lentinula's cultivation in 1987, China became large market in Lentinula cultivation. Amongst all cultivation methods used for $L$. edodes, cultivation on wooden logs and cultivation on synthetic substrates are the most practiced ones. Lentinula edodes was first cultivated on wood logs in China as a method to enhance basidiome production of the wild strains (Chang \& Miles 1987, Miles \& Chang 2004). With the use of scientific technology much later, cultivation techniques evolved to inoculation of pure Lentinula mycelia onto natural logs. The use of synthetic log cultivation is nowadays widely practiced in not only Southeast Asia but also in European countries, Australia and New Zealand (Chen 2001).

Lentinula edodes is usually commercially cultivated on both wood logs placed on forest floors and indoors on synthetic substrates (Chen 2001, Miles \& Chang 2004, Kobayashi et al. 2020). Traditionally, L. edodes was cultivated on wooden logs of Castanopsis cuspidate in Japan, but the most common ones use nowadays are species of Quercus, Castanopsis, Lithocarpus and Carpinus (Miles \& Chang 2004). Although L. edodes grows on all logs regardless of the age or diameter, uniform logs are preferred for convenient handling. One--meter long wooden logs with 7 $-15 \mathrm{~cm}$ in diameter are usually cut after the leaves fall off. Carbohydrates and other nutrients in the logs are highest during these seasons (Chang \& Miles 1987). Inoculation holes are drilled into the logs and these are plugged with L. edodes spawn. Once inoculated, these logs are placed in cool and humid areas for faster mycelial growth. In order to stimulate mycelial growth, the logs may be banged with hammers as part of a shock treatment (Chang \& Miles 1987). Basidiome production, in general, depends on the surrounding environmental conditions. Usually, the logs are either arranged in upright positions in rows, leaning against other logs as supporters and sprinkled with water, or housed in beds inside greenhouses with the temperature maintained at $15-20{ }^{\circ} \mathrm{C}$ and humidity at $80-90 \%$. However, with logging bans and laws against deforestation due to the negative environmental impact, other alternatives had to be explored for better ecological and economic advantages.

Synthetic $\operatorname{logs}$ are used as an eco-friendly alternative for more intensive cultivation of Lentinula. Cultivation techniques using different formulations of substrates have been developed and optimized over years for optimum biological efficiency. By using synthetic logs under controlled or semi-controlled environments for cultivation, techniques have rapidly been improved for shorter production time and higher yield of L. edodes. Growers can select the best from agricultural wastes such as oak sawdust, cereal straw, corn cobs, and sugarcane bagasse as the main basal ingredient for their substrate formulations (Özçelik \& Pekşen 2007). These can be used alone or in combination with other wastes productions and other starch-based supplements to provide better nutrition for mycelial growth. Sawdust is one of the most popular ingredients used for substrate formulations in Lentinula cultivation. A widely used standard formulation in the US consists of $80 \%$ sawdust and $20 \%$ of supplements (bran, wheat, millets or sugarcane molasses) on a dried weight basis (Miller \& Jong 1987). Özçelik \& Pekşen (2007) reported the possibility of using hazelnut husks as a basal ingredient for substrate preparation in $L$. edodes cultivation. 
Zervakis et al. (2001) compared seven substrates (wheat straw, cotton gin-trash, peanut shells, poplar sawdust, oak sawdust, corn cobs, and olive press-cake) for the cultivation of L. edodes, and reported wheat straw as the best one. The comparative study by Philippoussis et al. (2003) showed that heavier basidiomes of Lentinula are produced when oak-wood sawdust and wheat straw are used as substrates. The substrate formulation used by Yu et al. (2021) composing of 50\% corncob, $28 \%$ sawdust, $20 \%$ wheat bran, and $2 \%$ gypsum, showed the excellent potential of corncob as the main ingredient with $80 \%$ biological efficiency.

Attempts to cultivate Lentinula boryana have been made by several groups (Mata et al. 2001, Sobal et al. 2010, Gaitán-Hernández \& Salmones 2015). During the comparative study of Mata et al. (2000), it was shown that L. boryana could not produce basidiomes when it is cultivated under the same conditions as L. edodes. Mata et al. (2001) also compared the growth of $L$. edodes and $L$. boryana on wheat straw. L. boryana had a relatively slow growth as compares to L. edodes. GaitánHernández \& Salmones (2015) demonstrated that supplementation of straw -vineyard pruning with $\mathrm{CaSO}_{4}$ and $\mathrm{Ca}(\mathrm{OH})_{2}$ allowed better mycelial growth and primordia formation for L. boryana. However, not all primordia turned into basidiomes, resulting in low biological efficiency. Mata \& Mishra (2005) were able to grow L. aciculospora, L. novaezelandiae, and L. raphanica, with the latter growing fastest at an optimum temperature of $25{ }^{\circ} \mathrm{C}$. Few experimental trials have been focused on the mycelial growth of other Lentinula species but further studies are still needed for the cultivation trials (Singh \& Singh 2005, Kim et al. 2009, Mata \& Mishra 2015).

\section{Economic importance}

Lentinula edodes is one of the edible species largely consumed worldwide (Royse et al. 2017). With the considerable shift in the diets and lifestyles of people in the last decades due to urbanization, consumers are becoming more aware of the increase in diseases, hence moving towards functional foods. The demand for shiitake has been increasing significantly as they are incorporated in functional foods and beverages to improve nutritional values. Lentinula edodes is also widely used in the pharmaceutical industry for treating colds, boosting the immune systems, as antiaging agents (Muszyńska et al. 2017, Lee et al. 2020, Murphy et al. 2020). Many countries' economy is thriving with the applicability of Lentinula in food and nutraceutical industries. The global shiitake market was valued at \$ 590.52 million in 2020 and is expected to grow at $21.13 \%$ by 2027 (KTVN 2021). The rising application of shiitake in developing countries due to the economic viability is further bringing various job opportunities for local people. Lentinula cultivation activities can become a source of additional income for farmers. Trading of cultivated mushrooms are done locally, regionally and internationally, thus, providing opportunities to improve national economy and building relationships between countries (Hyde et al. 2019). Mushroom cultivation market is projected to reach $\$ 20.4$ billion by 2025 , with Lentinula being the fastest growing in the market (Markets 2021). The cost effectiveness of mushroom growing in developing countries has attracted the interest of many growers for better profits. The availability of agricultural wastes that act as substrates for mushroom cultivation is expected to further boost production in these countries.

\section{Acknowledgements}

We would like to thank Thailand Science Research and Innovation (TSRI) grant, Macrofungi diversity research from the Lancang-Mekong Watershed and surrounding areas (Grant No. DBG6280009).

\section{References}

Ahmed WA, Osman ME, Khattab OH, Hassan FRH et al. 2011 - Studies of ethanolic extract from Lentinus edodes on different cell lines and lymphocytes separated from cancer breast patients. Cancer Biology 1(2), 1-9. 
Aoki T. 1984 - Lentinan. In: Fenichel, R.L., Chigris, M.A. (Eds.), Immune Modulation Agents and Their Mechanism. Marcel Dekker, Inc., New York and Basel, 63-77.

Bach F, Helm CV, Bellettini MB, Maciel GM et al. 2017 - Edible mushrooms: a potential source of essential amino acids, glucans and minerals. International Journal of Food Science \& Technology 52(11), 2382-2392.

Barros L, Calhelha RC, Vaz JA, Ferreira IC et al. 2007 - Antimicrobial activity and bioactive compounds of Portuguese wild edible mushrooms methanolic extracts. European Food Research and Technology 225(2), 151-156.

Bhutta ZA, Sadiq K, Aga T. 2013 - Protein digestion and bioavailability. Encyclopedia of Human Nutrition 4, 66-73.

Bisen PS, Baghel RK, Sanodiya BS, Thakur GS et al. 2010 - Lentinus edodes: a macrofungus with pharmacological activities. Current Medicinal Chemistry 17(22), 2419-2430.

Cao X, Xia Y, Liu D, He Y et al. 2020 - Inhibitory effects of Lentinus edodes mycelia polysaccharide on $\alpha$-glucosidase, glycation activity and high glucose-induced cell damage. Carbohydrate Polymers 246, 1-36.

Chang R. 1996 - Functional properties of edible mushrooms. Nutrition Reviews 54(11), S91.

Chang ST. 2008 - Overview of mushroom cultivation and utilization as functional foods. Mushrooms as functional foods, Wiley-Interscience; 1st edition.

Chang ST, Miles PG. 1987 - Historical record of the early cultivation of Lentinus in China, Mushroom Journal of the Tropics 7, 31-37.

Chen AW. 2001 - Cultivation of Lentinula edodes on synthetic logs. Mushroom Growers' Newsletter 10(4), 3-9.

Chen S, Liu C, Huang X, Hu L et al. 2020 - Comparison of immunomodulatory effects of three polysaccharide fractions from Lentinula edodes water extracts. Journal of Functional Foods $66,1-6$.

Chibata I, Okumura K, Takeyama S, Lentinacin K. 1969 - A new hypocholesterolemic substance in Lentinus edodes. Experientia 25, 1237-1238.

Chihara G. 1992 - Immunopharmacology of Lentinan, a polysaccharide isolated from Lentinus edodes: its applications as a host defence potentiator. International Journal of Oriental Medecine 17, 57-77.

Chowdhury MMH, Kubra K, Ahmed SR. 2015 - Screening of antimicrobial, antioxidant properties and bioactive compounds of some edible mushrooms cultivated in Bangladesh. Annals of Clinical Microbiology and Antimicrobials 14(1), 1-6.

Chung IM, Kim SY, Han JG, Kong WS et al. 2020 - Fatty acids and stable isotope ratios in shiitake mushrooms (Lentinula edodes) indicate the origin of the cultivation substrate used: a preliminary case study in Korea. Foods 9(9), 1-13.

Ciric L, Tymon A, Zaura E, Lingström P et al. 2011 - In vitro assessment of shiitake mushroom (Lentinula edodes) extract for its antigingivitis activity. Journal of Biomedicine and Biotechnology, 1-7.

Crespo H, Guillén H, de Pablo-Maiso L, Gómez-Arrebola C et al. 2017 - Lentinula edodes $\beta$ glucan enriched diet induces pro-and anti-inflammatory macrophages in rabbit. Food \& Nutrition Research 61(1), 1-8.

De Silva DD, Rapior S, Fons F, Bahkali AH et al. 2012 - Medicinal mushrooms in supportive cancer therapies: an approach to anti-cancer effects and putative mechanisms of action. Fungal Diversity 55(1), 1-35.

Dennert G, Tucker D. 1973 - Antitumor Polysaccharide Lentinan-AT Cell Adjuvant. Journal of the National Cancer Institute 51(5), 1727-1729.

Din SRU, Zhong M, Nisar MA, Saleem MZ et al. 2020 - Latcripin-7A, derivative of Lentinula edodes $\mathrm{C}$ 91-3, reduces migration and induces apoptosis, autophagy, and cell cycle arrest at G 1 phase in breast cancer cells. Applied Microbiology and Biotechnology 104(23), 1016510179. 
Earle FS. 1909 - The genera of North American gill fungi. Bulletin of the New York Botanical Garden. (5) 373-451

Enman J, Rova U, Berglund K. A. 2007 - Quantification of the bioactive compound eritadenine in selected strains of shiitake mushroom (Lentinus edodes). Journal of Agricultural and Food Chemistry 55(4), 1177-1180.

FAOSTAT. Mushrooms and Truffles [Internet]. 2021 - Available from: http://www.fao.org/faostat/en/\#data/QC (Accessed on August 12, 2021)

Finimundy TC, Dillon AJP, Henriques JAP, Ely MR. 2014 - A review on general nutritional compounds and pharmacological properties of the Lentinula edodes mushroom. Food and Nutrition Sciences, 1-12.

Finimundy TC, Gambato G, Fontana R, Camassola M et al. 2013 - Aqueous extracts of Lentinula edodes and Pleurotus sajor-caju exhibit high antioxidant capability and promising in vitro antitumor activity. Nutrition Research 33(1), 76-84.

Fulgoni III VL, Agarwal S. 2021 - Nutritional impact of adding a serving of mushrooms on usual intakes and nutrient adequacy using National Health and Nutrition Examination Survey 2011-2016 data. Food Science \& Nutrition 9(3), 1504-1511.

Fuji T, Maeda H, Suzuki F, Ishida N. (1978) - Isolation and characterization of a new antitumor polysaccharide, KS-2, extracted from culture mycelia of Lentinus edodes. The Journal of Antibiotics 31(11), 1079-1090.

Fukushima-Sakuno E. 2020 -Bioactive small secondary metabolites from the mushrooms Lentinula edodes and Flammulina velutipes. The Journal of Antibiotics 73(10), 687-696.

Gaitán-Hernández R, Salmones D. 2015 - Use of lignocellulosic residues to optimize spawn production and carpophore formation of the edible mushroom Lentinula boryana. Revista Mexicana de Ciencias Agrícolas 6(7), 1639-1652.

Garcia J, Afonso A, Fernandes C, Nunes FM et al. 2021 - Comparative antioxidant and antimicrobial properties of Lentinula edodes Donko and Koshin varieties against priority multidrug-resistant pathogens. South African Journal of Chemical Engineering 35, 98-106.

Gordon M, Guralnik M, Kaneko Y, Mimura T et al. 1995 - A phase II-controlled study of a combination of the immune modulator, lentinan, with didanosine (ddI) in HIV patients with CD4 cells of 200-500/mm3. Journal of Medicine 26, 193-207.

Gu YH, Belury MA. 2005 - Selective induction of apoptosis in murine skin carcinoma cells (CH72) by an ethanol extract of Lentinula edodes. Cancer Letters 220(1), 21-28.

Guillamón E, García-Lafuente A, Lozano M, Rostagno MA et al. 2010 - Edible mushrooms: role in the prevention of cardiovascular diseases. Fitoterapia 81(7), 715-723.

Günç Ergönül P, Akata I, Kalyoncu F, Ergönül B. 2013 - Fatty acid compositions of six wild edible mushroom species. The Scientific World Journal 2013(4), 1-4.

Guo Z, Hu Y, Wang D, Ma X et al. 2009 - Sulfated modification can enhance the adjuvanticity of lentinan and improve the immune effect of ND vaccine. Vaccine 27(5), 660-665.

Guzmán G, Salmones D, Tapia F. 1997 - Lentinula boryana, morphological variations, taxonomic position, distribution and relationships with Lentinula edodes and related species. Reports of the Tottori Mycological Institute (Japan).

Haro A, Trescastro A, Lara L, Fernández-Fígares I et al. 2020 - Mineral elements content of wild growing edible mushrooms from the southeast of Spain. Journal of Food Composition and Analysis 91, 1-30.

Hatvani N. 2001 - Antibacterial effect of the culture fluid of Lentinus edodes mycelium grown in submerged liquid culture. International Journal of Antimicrobial Agents 17(1), 71-74.

He MQ, Zhao RL, Hyde KD, Begerow D, et al. 2019 - Notes, outline and divergence times of Basidiomycota. Fungal Diversity. 99(1),105-367.

Hearst R, Nelson D, McCollum G, Millar BC et al. 2009 - An examination of antibacterial and antifungal properties of constituents of Shiitake (Lentinula edodes) and Oyster (Pleurotus ostreatus) mushrooms. Complementary Therapies in Clinical Practice 15(1), 5-7. 
Hibbett DS. 2001 - Shiitake mushrooms and molecular clocks: historical biogeography of Lentinula. Journal of Biogeography 28(2), 231-241.

Hibbett DS, Hansen K, Donoghue MJ. 1998 - Phylogeny and biogeography of Lentinula inferred from an expanded rDNA dataset. Mycological Research 102(9), 1041-1049.

Hirasawa M, Shouji N, Neta T, Fukushima K, Takada K.et al. 1999 - Three kinds of antibacterial substances from Lentinus edodes (Berk.) Singer. (Shiitake, an edible mushroom). International Journal of Antimicrobial Agents 11(2), 151-157.

Hiroko R, Megumi MC, Dantas MC. 2005 - Growth and antibacterial activity of Lentinula edodes in liquid media supplemented with agricultural wastes. Electronic Journal of Biotechnology 8(2), 94-99.

Hobbs C. 2000 - Medicinal value of Lentinus edodes (Berk.) Sing. (Agaricomycetideae). A literature reviews. International Journal of Medicinal Mushrooms 2(4), 287-302.

Hou X, Zhang N, Xiong S, Li S, Yang B. 2008 - Extraction of BaChu mushroom polysaccharides and preparation of a compound beverage. Carbohydrate Polymer 73(2), 289-294

Hyde KD, Xu J, Rapior S, Jeewon R et al. 2019 - The amazing potential of fungi: 50 ways we can exploit fungi industrially. Fungal Diversity 97(1), 1-136.

Ina K, Kataoka T, Ando T. 2013 - The use of lentinan for treating gastric cancer. Anti-Cancer Agents in Medicinal Chemistry 13(5), 681-688.

Ishikawa NK, Kasuya MCM, Vanetti MCD. 2001 - Antibacterial activity of Lentinula edodes grown in liquid medium. Brazilian Journal of Microbiology 32, 206-210.

Israilides C, Kletsas D, Arapoglou D, Philippoussis A et al. 2008 - In vitro cytostatic and immunomodulatory properties of the medicinal mushroom Lentinula edodes. Phytomedicine $15,512-519$.

Jang HL, Park SY, Nam JS. 2017 - Effect of extraction solvent on the antioxidant activity of Lentinula edodes GNA01 extract. The Korean Journal of Food and Nutrition 30(1), 51-58.

Jong SC, Birmingham M. 1993 - Medicinal and therapeutic value of the shiitake mushroom. Advanced Applied Microbiology 39, 153-184.

Joseph TP, Zhao Q, Chanda W, Kanwal S et al. 2021 - Expression and in vitro anticancer activity of Lp16-PSP, a member of the YjgF/YER057c/UK114 protein family from the mushroom Lentinula edodes C 91-3. Archives of Microbiology 203(3), 1047-1060.

Kalač P. 2013 - A review of chemical composition and nutritional value of wild-growing and cultivated mushrooms. Journal of the Science of Food and Agriculture 93(2), 209-218.

Kalač P. 2016 - Edible mushrooms: chemical composition and nutritional value. Academic Press.

Kamiya T, Saito Y, Hashimoto M, Seki H. 1969 - Structure and synthesis of lentysine, a new hypocholesterolemic substance. Tetrahedron Letter 10, 4729-4732.

Kaneko Y, Chihara G. 1992 - Potentiation of host resistance against microbial infections by Lentinan and its related polysaccharides. In: Friedman $\mathrm{H}$ et al. Microbial Infections. New York: Plenum, pp. 201-206.

Kennedy G, Nantel G, Shetty P. 2004 - Globalization of food systems in developing countries: impact on food security and nutrition. Food and Nutrition Paper 83, 1-300.

Kitzberger CSG, Smânia Jr A, Pedrosa RC, Ferreira SRS. 2007 - Antioxidant and antimicrobial activities of shiitake (Lentinula edodes) extracts obtained by organic solvents and supercritical fluids. Journal of Food Engineering 80(2), 631-638.

Kim KS, Kim GJ, Kim HS, Jin SW et al. 2009 - Cultural characteristics of unrecorded species Lentinula spp. in Korea. Journal of Mushroom 7(4), 193-199.

Kobayashi T, Oguro M, Akiba M, Taki H et al. 2020 - Mushroom yield of cultivated shiitake (Lentinula edodes) and fungal communities in logs. Journal of Forest Research, 25(4), 269275.

KTVN 2021-Mushroom Market Growing at CAGR of 21.13\%, Industry Size and Share Research with Knowledgeable Insights, Global Forecast Report 2021-2027 [online] Available at: https://www.ktvn.com/story/44879299/shiitake-mushroom-market-growing-at-cagr-of-2113- 
industry-size-and-share-research-with-knowledgeable-insights-global-forecast-report-20212027 (Accessed on November 4, 2021).

Kumar P, Chatli MK, Mehta N, Singh P et al. 2017- Meat analogues: Health promising sustainable meat substitutes. Critical Reviews in Food Science and Nutrition 57(5), 923-932.

Kupcova K, Stefanova I, Plavcova Z, Hosek J et al. 2018 - Antimicrobial, cytotoxic, antiInflammatory, and antioxidant activity of culinary processed shiitake medicinal mushroom (Lentinus edodes, Agaricomycetes) and its major sulfur sensory-active compound-Lenthionine. International Journal of Medicinal Mushrooms 20(2), 165-175

Lam SK, Ng TB. 2001 - Hypsin, a novel thermostable ribosome-inactivating protein with antifungal and antiproliferative activities from fruiting bodies of the edible mushroom Hypsizigus marmoreus. Biochemical and Biophysical Research Communications 285(4), 1071-1075.

Lee H, Lee K, Lee S, Lee J et al. 2020 - Ethyl acetate fraction of aqueous extract of Lentinula edodes inhibits Osteoclastogenesis by suppressing NFATc1 expression. International Journal of Molecular Sciences 21(4), 1347.

Li H, Tian Y, Menolli Jr N, Ye L et al. 2021 - Reviewing the world's edible mushroom species: A new evidence-based classification system. Comprehensive Reviews in Food Science and Food Safety 20(2), 1982-2014

Li S, Wang A, Liu L, Tian G et al.2018 - Evaluation of nutritional values of shiitake mushroom (Lentinus edodes) stipes. Journal of Food Measurement and Characterization 12, 2012-2019

Looney BP, Buyck B, Menolli N, Randrianjohany E et al. 2021 - Lentinula madagasikarensis sp. nov., a relative of shiitake mushrooms from Madagascar. Fungal Systematics and Evolution $8,1-8$.

Lu G, Fan L, Zhang Z, Pan H. 2009 - Development of research on lentinan. Acta Agriculturae Zhejiangensis 21(2),183-188.

Luan HQ, Shao LQ, Wang Y, Zhong MT et al. 2017 - Expression, purification and antitumor activity of Lentinula edodes Lactcripin-8 protein. Chinese Journal of Microecology 29, 10311036.

Marçal S, Sousa AS, Taofiq O, Antunes F et al. 2021 - Impact of postharvest preservation methods on nutritional value and bioactive properties of mushrooms. Trends in Food Science \& Technology 110, 418-431

Market data forecast 2021 - Mushroom Cultivation Market Size, Trends and Forecast to 2026. https://www.marketdataforecast.com/market-reports/mushroom-cultivation-market (accessed 11 March 2021).

Markets 2021 - Mushroom Cultivation Market worth \$20.4 billion by 2025 . https://www.marketsandmarkets.com/PressReleases/mushroom-cultivation.asp (Accessed on July 7, 2021).

Maruyama S, Sukekawa Y, Kaneko Y, Fujimoto S. 2006 - Anti-tumor activities of lentinan and micellapist in tumor-bearing mice. Gan To Kagaku - Ryoho 33, 1726-1729.

Mata JL, Petersen RH. 2000 - A new species of Lentinula (Agaricales) from Central America. Mycoscience. 41(4), 351-355

Mata JL, Petersen RH. 2001 - Type specimen studies in new world Lentinula. Mycotaxon 79, 217229

Mata G, Salmones D, Ortega PM. 2000 - Viability and mushroom production of Lentinula edodes and L. boryana strains (Fungi: Basidiomycetes) after cryogenic storage of spawn stocks. World Journal of Microbiology and Biotechnology 16(3), 283-287.

Mata G, Delpech PAND, Savoie JM. 2001 - Selection of strains of Lentinula edodes and Lentinula boryana adapted for efficient mycelial growth on wheat straw. Revista Iberoamericana de Micologia 18(3), 118-122.

Mata JL, Mishra, NT. 2015 - Comparative study of worldwide species of genus Lentinus (= Lentinula, higher Basidiomycetes) based on linear mycelium growth. International Journal of Medicinal Mushrooms 17(5), 481-489. 
Mattila P, Könkö K, Eurola M, Pihlava, JM et al. 2001 - Contents of vitamins, mineral elements, and some phenolic compounds in cultivated mushrooms. Journal of Agricultural and Food Chemistry 49(5), 2343-2348.

Miles PG, Chang ST. 2004 - Mushrooms: cultivation, nutritional value, medicinal effect, and environmental impact. CRC press.

Miller MW, Jong SC. 1987 - Commercial cultivation of shiitake in sawdust filled plastic bags. In: Wuest PJ, Royse DJ, Beelman RB. (Eds.), Developments in Crop Science, Cultivating Edible Fungi, vol. 10. Elsevier Science Publishers, BV Amsterdam, The Netherlands, pp. 421-426

Mizuno T. 1995 - Shiitake, Lentinus edodes: Functional properties for medicinal and food purposes. Food Reviews International 11(1), 109-128.

Moon S, Lee HY, Shim D, Kim M et al. 2017 - Development and molecular characterization of novel polymorphic genomic DNA SSR markers in Lentinula edodes. Mycobiology 45(2), 105-109.

Morales D, Rutckeviski R, Villalva M, Abreu H et al. 2020 - Isolation and comparison of $\alpha$-and $\beta$ D-glucans from shiitake mushrooms (Lentinula edodes) with different biological activities. Carbohydrate Polymers 229, 1-30.

Morales D, Tejedor-Calvo E, Jurado-Chivato N, Polo G et al. 2019 - In vitro and in vivo testing of the hypocholesterolemic activity of ergosterol-and $\beta$-glucan-enriched extracts obtained from shiitake mushrooms (Lentinula edodes). Food \& Function 10(11), 7325-7332.

Murphy EJ, Masterson C, Rezoagli E, O'Toole D et al. 2020 - $\beta$-Glucan extracts from the same edible shiitake mushroom Lentinus edodes produce differential in-vitro immunomodulatory and pulmonary cytoprotective effects-Implications for coronavirus disease (COVID-19) immunotherapies. Science of the Total Environment 732, 1-30.

Murrill WA. 1915 - Notes on Agaricus reticeps. Mycologia 7(5), 291.

Muszyńska B, Pazdur P, Lazur J, Sułkowska-Ziaja K. 2017 - Lentinula edodes (Shiitake)biological activity. Medicina Internacia Revuo-International Medicine Review 27(108), 189195.

Nakano H, Namatame K, Nemoto H, Motohashi H et al. 1999 - A multi-institutional prospective study of lentinan in advanced gastric cancer patients with unresectable and recurrent diseases: effect on prolongation of survival and improvement of quality of life. Hepatogastroenterology 46(28), 2662-2668.

Nisar J, Mustafa I, Anwar, H, Sohail MU et al. 2017 - Shiitake culinary-medicinal mushroom, Lentinus edodes (Agaricomycetes): a species with antioxidant, immunomodulatory, and hepatoprotective activities in hypercholesterolemic rats. International Journal of Medicinal Mushrooms 19(11).

Özçelik E, Pekşen A. 2007 - Hazelnut husk as a substrate for the cultivation of shiitake mushroom (Lentinula edodes). Bioresource technology 98(14), 2652-2658.

Öztürk M, Tel-Çayan G, Muhammad A, Terzioğlu P et al. 2015 - Mushrooms: a source of exciting bioactive compounds. In Studies in Natural Products Chemistry 45, 363-456.

Pegler DN. 1976 - The classification of the genus Lentinus Fr. (Basidiomycota). Kavaka 3, 11-20

Pegler DN. 1983 - The genus Lentinula (Tricholomataceae tribe Collybieae). Sydowia 36, 227-239

Philippoussis A, Diamantopoulou P, Zervakis G. 2003 - Correlation of the properties of several lignocellulosic substrates to the crop performance of the shiitake mushroom Lentinula edodes. World Journal of Microbiology and Biotechnology 19, 551-557

Rao JR, Millar BC, Moore JE. 2009 - Antimicrobial properties of shiitake mushrooms (Lentinula edodes). International Journal of Antimicrobial Agents 33(6), 591-592.

Rathore H, Prasad S, Sharma S. 2017 - Mushroom nutraceuticals for improved nutrition and better human health: A review. Pharma Nutrition 5(2), 35-46.

Reis FS, Barros L, Martins A, Ferreira IC. 2012 - Chemical composition and nutritional value of the most widely appreciated cultivated mushrooms: an inter-species comparative study. Food and Chemical Toxicology 50(2), 191-197. 
Ren Z, Li J, Song X, Zhang J et al. 2018 - The regulation of inflammation and oxidative status against lung injury of residue polysaccharides by Lentinula edodes. International Journal of Biological Macromolecules 106, 185-192.

Rincão VP, Yamamoto KA, Ricardo NMPS, Soares SA et al. 2012 - Polysaccharide and extracts from Lentinula edodes: structural features and antiviral activity. Virology Journal 9(1), 1-6.

Roncero-Ramos I, Delgado-Andrade C. 2017 - The beneficial role of edible mushrooms in human health. Current Opinion in Food Science 14, 122-128.

Royse DJ, Baars J, Tan, Q. 2017 - Current overview of mushroom production in the world. Edible and Medicinal Mushrooms, 5-13.

Saito H, Ohki T, Takasuka N, Sasaki TA. 1977 - 13C-N.M.R.-spectral study of a gelforming, branched (1!3)- $\beta$-d-glucan, (lentinan) from lentinus edodes, and its aciddegraded fractions. Structure, and dependence of conformation on the molecular weight. Carbohydrate Research 58(2), 293-305.

Sasaki T, Takasuka N. 1976 - Further study of the structure of lentinan, an anti-tumor polysaccharide from Lentinus edodes. Carbohydrate Research 47(1), 99-104.

Sasidharan S, Aravindran S, Latha LY, Vijenthi R et al. 2010 - In vitro antioxidant activity and hepatoprotective effects of Lentinula edodes against paracetamol-induced hepatotoxicity. Molecules 15(6), 4478-4489.

Seo S, Park Y, Jang Y, Ka KH. 2017 -. Antioxidant properties of Lentinula edodes after sawdust bag cultivation with different oak substrates. The Korean Journal of Mycology 45(2), 121131.

Shah SK, Walker PA, Moore-Olufemi SD, Sundaresan A et al. 2011 - An evidence-based review of a Lentinula edodes mushroom extract as complementary therapy in the surgical oncology patient. Journal of Parenteral and Enteral Nutrition 35(4), 449-458.

Singh TC, Singh, NI. (2005). Cultural studies on growth of two isolates of Lentinula lateritia. Journal of Mycopathological Research 43(2), 267-269.

Siwulski M, Rzymski P, Budka A, Kalač P et al. 2019 - The effect of different substrates on the growth of six cultivated mushroom species and composition of macro and trace elements in their fruiting bodies. European Food Research and Technology 245(2), 419-431.

Sobal M, Morales P, Bonilla M et al. 2010 - Formulations for the intensive production of Lentinula edodes and L. boryana in Mexico. Hacia un desarrollo sostenible del sistema de producciónconsumo de los hongos comestibles y medicinales en latinoamérica: avances y perspectivas en el siglo 21, 175-187.

Song X, Ren Z, Wang X, Jia L et al. 2020 - Antioxidant, anti-inflammatory and renoprotective effects of acidic-hydrolytic polysaccharides by spent mushroom compost (Lentinula edodes) on LPS-induced kidney injury. International Journal of Biological Macromolecules 151, 1267-1276.

Spim SRV, Castanho NRCM, Pistila AMH et al. 2021 - Lentinula edodes mushroom as an ingredient to enhance the nutritional and functional properties of cereal bars. Journal of Food Science and Technology 58(4), 1349-1357.

Sugano N, Choji Y, Hibino Y, Yasumura S et al. 1985 - Anticarcinogenic action of an alcoholinsoluble fraction (LAP1) from culture medium of Lentinus edodes mycelia. Cancer letters 27(1), 1-6.

Suzuki M, Takatsuki F, Maeda YY, Hamuro J, Chihara Get al. 1994 - Antitumor and immunological activity of Lentinan in comparision with LPS. International Journal of Immunopharmacology 16, 463-468.

Suzuki N, Takimoto Y, Suzuki R, Arai T et al. 2013 - Efficacy of oral administration of Lentinula edodes mycelia extract for breast cancer patients undergoing postoperative hormone therapy. Asian Pacific Journal of Cancer Prevention 14(6), 3469-3472.

Taguchi T. 1987 - Clinical efficacy of lentinan on patients with stomach cancer: end point results of a four-year follow-up survey. Cancer Detection and Prevention Supplement 1, 333-349. 
Tanaka K, Ishikawa S, Matsui Y, Kawanishi T et al. 2012 - Combining a peptide vaccine with oral ingestion of Lentinula edodes mycelia extract enhances anti-tumor activity in B16 melanomabearing mice. Cancer Immunology, Immunotherapy 61(11), 2143-2152.

Thatoi H, Singdevsachan SK. 2014 - Diversity, nutritional composition and medicinal potential of Indian mushrooms: A review. African Journal of Biotechnology 13(4), 523-545.

Tonucci-Zanardo NM, Pascholati SF, Di Piero RM. 2015 - In vitro antimicrobial activity of aqueous extracts from Lentinula edodes isolates against Colletotrichum sublineolum and Xanthomonas axonopodis pv. Passiflorae. Summa Phytopathologica 41, 13-20.

Valverde ME, Hernández-Pérez T, Paredes-López O. 2015 - Edible mushrooms: improving human health and promoting quality life. International journal of microbiology, 1-14.

Vetter J. 2007 -. Chitin content of cultivated mushrooms Agaricus bisporus, Pleurotus ostreatus and Lentinula edodes. Food Chemistry 102(1), 6-9.

Wang S, Welte T, Fang H et al. 2009 - Oral Administration of Active Hexose Correlated Compound Enhances Host Resistance to West Nile Encephalitis in Mice. The Journal of Nutrition 139, 598-602.

Wang J, Li W, Huang X, Liu Y et al. 2017 - A polysaccharide from Lentinus edodes inhibits human colon cancer cell proliferation and suppresses tumor growth in athymic nude mice. Oncotarget 8(1), 610 .

Wang J, Zhou Z, Dan D, Hu G. 2020 -Physicochemical properties and bioactivities of Lentinula edodes polysaccharides at different development stages. International Journal of Biological Macromolecules 150, 573-577.

Wang L, Brennan MA, Guan W, Liu J et al. 2021 - Edible mushrooms dietary fibre and antioxidants: effects on glycaemic load manipulation and their correlations pre-and postsimulated in vitro digestion. Food Chemistry, 1-30

Wang XM, Zhang J, Wu LH, Zhao YL et al. 2014 - A mini-review of chemical composition and nutritional value of edible wild-grown mushroom from China. Food Chemistry 151, 279-285.

Wasser SP. 2005 - Shiitake (Lentinus edodes). Encyclopedia of dietary supplements, 653-664.

Wasser SP, Weis AL. 1999 - Medicinal properties of substances occurring in higher basidiomycetes mushrooms: current perspectives. International Journal of Medicinal Mushrooms 1(1).

Yamaguchi Y, Miyahara E, Hihara J. 2011 - Efficacy and safety of orally administered Lentinula edodes mycelia extract for patients undergoing cancer chemotherapy: a pilot study. The American Journal of Chinese Medicine 39(03), 451-459.

Yasumoto K, Iwami K, Mitsuda H. 1971 - A new sulfur-containing peptide from Lentinus edodes acting as a precursor for lenthionine. Agricultural and Biological Chemistry 35(13), 20592069.

Yu H, Zhang D, Zhang L, Li Q et al. 2021 - Corncob as a Substrate for the Cultivation of Lentinula edodes, 1-13

Zervakis G, Philippoussis A, Ioannidou S et al. 2001 - Mycelium growth kinetics and optimal temperature conditions for the cultivation of edible mushroom species on lignocellulosic substrates. Folia Microbiology 46, 231-239

Zhang Y, Zhang M, Jiang Y, Li X et al. 2018 - Lentinan as an immunotherapeutic for treating lung cancer: a review of 12 years clinical studies in China. Journal of Cancer Research and Clinical Oncology 144(11), 2177-2186.

Zhao Y, Bi J, Yi J, Jin X et al. 2019 - Evaluation of sensory, textural, and nutritional attributes of shiitake mushrooms (Lentinula edodes) as prepared by five types of drying methods. Journal of Food Process Engineering 42(4), 1-13.

Zhong M, Liu B, Liu Y, Wang X et al. 2012 - The antitumor activities of Lentinula edodes C91-3 mycelia fermentation protein on S180 (Mouse sarcoma cell) in vivo and in vitro. Journal of Medicinal Plants Research 6(12), 2488-2492. 